\title{
Distribution of Marine Fungi and Fungus-Like Organisms in the South China Sea and Their Potential Use in Industry and Pharmaceutical Application
}

\author{
E.B. Gareth Jones ${ }^{1 *}$, SitiAisyah Alias ${ }^{1}$ and Ka-Lai Pang ${ }^{2}$ \\ ${ }^{1}$ Institute of Ocean and Earth Sciences (IOES), C308, Institute of Postgraduate Studies Building, University of Malaya, \\ 50603 Kuala Lumpur, Malaysia. \\ ${ }^{2}$ Institute of Marine Biology and Center of Excellence for Marine Bioenvironment and Biotechnology, National Taiwan \\ Ocean University, No. 2 Pei-Ning Road, Keelung 20224, Taiwan (R.O.C.) \\ *torperadgj@gmail.com (corresponding author)
}

\begin{abstract}
In this article we document the distribution and ecology of marine fungi in the South China Sea. They have been widely studied in this area, resulting in approximately a third of all described marine fungi (560 species) reported from the South China Sea, and especially from Hong Kong, Malaysia, Thailand and Taiwan. Sixty-nine marine fungi have been described from countries bordering the South China Sea, mainly ascomycetes species, with many from Malaysia (25 species). Many of the fungi documented have been found on mangrove substrates, including attached and drift mangrove wood. This has resulted in detailed studies of their vertical and horizontal distribution in mangroves, and sequence of colonisation on submerged test blocks. Many marine fungi isolated from the South China Sea have been screened for new chemical structures with bioactivity. Foremost has been Professor Y. C. Lin and his colleagues at Guangzhou University who have described a wide range of chemical structures including 42 new or novel compounds and 35 known compounds from 25 fungal strains (comprising endophytes, obligate and marine-derived fungi). Although filamentous fungi have been widely collected in the South China Sea, information on chytrids, mucoraceous fungi and fungal-like organisms is meagre and warrants further investigation.
\end{abstract}

(Keywords: distribution, ecology marine fungi, South China Sea, omega-3-fatty acids, bioactive compounds, industrial application).

\section{INTRODUCTION}

In comparison to other marine organisms, fungi and fungus-like organisms are not as numerous, but yet play a vital role in the recycling of organic matter in marine environments [46][61][76][83]. The Ascomycota, Basidiomycota and asexual morphs are the best known groups of marine fungi as testified by the number of books published [30][41][38]. Few marine members of the Chytridiomycota have been described and are rarely included in general books or reviews, while marine yeasts are generally documented in reviews on yeasts [15][43]. However, the book "Marine Fungi and Fungal-like Organisms" [35] offers a broad coverage of all taxonomic groups, their phylogeny, ecology and industrial application.

In this article we wish to consider four topics:

- the organisms,

- their occurrence and distribution of marine fungi in the South China Sea,
- $\quad$ chemical structures from marine fungi,

- $\quad$ production of omega-3-fatty acids, and,

- conclusions.

\section{MARINE FUNGI AND FUNGUS-LIKE ORGANISMS}

Various estimates have been made of the number of marine fungi and much depends on the criteria used to characterise these organisms. Many mycologists no longer use the straight jacket terms obligate and facultative marine organisms, but rather accept a broad ecological definition of all that are repeatedly collected or isolated from marine habitats [33]. Early studies tend to consider only fungi sporulating on the substrate, ignoring those present in the water columns as plankton or single cells, e.g. marine yeasts [16]. The current number of described marine fungi stands as 530 species in the Ascomycota, Basidiomycota and asexual 
morphs [38]. However this figure does not include the Chytridiomycota and yeasts. Estimates of the number of marine fungi and fungus-like organisms are presented in Tables 1 and 2, respectively.

So where are the missing fungi to be found? Substrates most intensively studied for the occurrence of marine fungi have been driftwood, intertidal attached wood, and trapped wood in rocks, mangrove wood, saltmarsh grasses and on seaweeds. Even so these collections are restricted to locations where marine mycologists work: Asia, Europe, Americas, while others have hardly been sampled for marine fungi, e.g. Africa, Antarctic waters.

\section{OCCURRENCE AND DISTRIBUTION OF MARINE FUNGI IN THE SOUTH CHINA SEA}

From a geographical point of view, marine fungi in Asia have been well served from the extensive work by many strong research teams in the countries bordering the South China Sea: Hong Kong [86][5][37], Brunei, Indonesia [22], Malaysia [1][2][26], Philippines [17] [40][5], Singapore [79][51], Taiwan [66] and Thailand [23][24][70][78](Figure 1). Coastal waters of mainland China remain largely unexplored with only reports of marine fungi from the islands Macau and Hainan [87] [88]. These studies resulted in the description of a wide range of new marine fungi: Calathella mangrovei [34], Caryospora mangrovei [23], Diaporthe salsuginosa and Aniptodera haispora [87], Phragmitensis marina [89], and Sedecimiella taiwanensis [65], to mention but a few.

Sixty-nine marine fungi have been described from countries bordering the South China Sea, mainly ascomycetes species (Table 3). No fewer than 25 new species were described from Malaysia and 18 from Brunei, with only four from Singapore. This reflects the intense studies of marine and mangrove fungi by Kevin Hyde in Brunei, Hong Kong and Thailand.

The number of marine fungi recorded for the South China Sea varies from country to country, depending on the intensity of collecting, with only five for Vietnam (E.B.G. Jones unpublished data) to over 139 for Malaysia (Table 4).

Many of the marine fungi documented for the South China Sea are mangrove species occurring on a wide range of mangrove trees, especially those on Avicennia, Bruguiera, Kandelia and Rhizophora species [75]. These biodiversity studies have enabled the characterization of a core group of mangrove fungi, although differences occur between individual mangroves [1][75] (Table 4). Two monographs have been published for the mangrove fungi of Malaysia [1] and Taiwan [66], illustrating 18 and 54 species, respectively.

Studies of marine fungi in the South China Sea have covered a wide range of topics: horizontal [2] and vertical distribution in mangroves [24][2], sequence of colonization of exposed timber [79][51], decomposition of lignocellulose and patterns of decay [68][56], endophytes of mangrove trees [31][62][7][71], and which have contributed immensely to our understanding of the biology, ecology and distribution of mangrove fungi. As a result of these investigations, marine fungi have been isolated into axenic culture and used for screening of bioactive compounds (see section 3). They have also enabled phylogenetic studies of selected taxa leading to the discovery of a number of new lineages of marine fungi [71].

Fungus-like organisms in the South China Sea have fared less well when it comes to their study with published data from Hong Kong [49][50][48][12][14], Philippines [44][45] and Thailand [82]. These studies have focused on their biodiversity in coastal mangroves [50][12][28], zoospore chemotaxis [14], utilization of food processing waste [11], tolerance to heavy metals [54], source of animal feed in marine aquaculture [29], and their growth and polyunsaturated fatty acid production (PUFA), in particular docosapentaneoic acid (DHA) [11][82] (see section 4).

Other fungus-like organisms include Halophytophthora, Haliphthoros and Sirolpidium species, with some causing diseases of marine animals such as abalone, lobster, and prawns, generally of eggs or larvae [18]. Hatai et al. (1980) described Haliphthoros philippinensis as a parasite of cultivated larvae of jumbo tiger prawn (Penaeus japonicus), and subsequently parasitic on eggs of captive mud crab (Scylla serrata) by Leano (2002). Halophytophthora species have been widely collected on senescent mangrove leaves in the intertidal zone with new species described from Taiwan [21][20], and Thailand [59]. An up-to-date list of fungus-like organisms reported from the South China Sea can be found in Marano et al. (2012).

\section{CHEMICAL STRUCTURES FROM MARINE FUNGI}

Marine fungi have attracted much attention in the search for new sources of biodiversity for screening 
for new chemical structures with antimicrobial activity. The first antibiotic documented from a marine fungus was siccayne [42] from the marine basidiomycetes Halocyphina villosa, a compound also known from a terrestrial fungus Helminthosporium siccans. Ebel (2012) estimates that some 1,100 new compounds are known from marine fungi, with over 100 published each year from 2007-2010. All major groups of chemical structures are documented for marine derived-fungi: polyketides (41\%), alkaloids (20\%), peptides (12 $\%)$, terpenoids (14\%), prenylatedpolyketides (8\%), shikimates 2\%) and lipids (1\%) [69].

Many university departments and research organisations have investigated the potential of marine fungi from the South China Sea to produce new or novel chemical structures. Foremost have been Professor Y. C. Lin and his colleagues at Guangzhou University who have described a wide range of chemical structures from fungi in the South China Sea. Pan et al. (2008) documented the bioactive compounds obtained from 25 fungal strains (comprising endophytes, obligate and marine-derived fungi) with 42 new or novel compounds and 35 known compounds. Some of the new compounds they described include: xyloketals A-H from a Xylaria sp. found growing on seeds in Mai Po Mangrove, Hong Kong [55], eutypoid A, a new lactone from Eutypa sp., and seven anthroquinones from a strain of the ascomycete Halorosellinia [90].

Chinese scientists have also described new compounds from fungi, plants and animals collected from the tropical island of Hainan, China [58][73]. An unidentified endophytic fungus isolated from the mangrove plant Scyphiphora hydrophyllavea yielded four new meroterpenes (guignardones 1-4) and two known guignardones $A$ and $B$ [58], with guignardone 1 showing modest activity against Staphylococcus aureus and MRSA.

Many new compounds have been described by scientists at BIOTEC, Thailand: five aigialomycins A-E which are 14-membered resorcyclic macrolides and one hypothemycin [27], and aigialone A and aigialospirol A (a hypothemycin related compound) two structurally unique compounds [84], all from the mangrove ascomycete Aigialus parvus. Halorosellinia oceanica is a prolific producer of novel compounds, including cytochalasin Q, 5-carboxymellein and halorosellinic acid (an ophiobolane sesterterpene) reported from a Thai strain (Chinworrungsee et al. 2001). Another Thai group working on natural products research is from Prince of Songkla University under the leadership of Professor
Vatcharin Rukachaisirikul that screens marine-derived fungi from the sea fan Annella sp. and endophytes of mangrove trees. Many new chemical structures have been reported, such as, epxydons and pyrones from the marine-derived Nigrospora sp. [80] and anthraquinone, cyclopentanone and napththoquinone derivatives from a Fusarium sp. isolated from the sea fan Annella [81].

Debbab et al. (2012) opine that marine fungal endophytes remain an underexplored group when compared with their bacterial counterparts and fungi from terrestrial habitats, a feature also commented on by Jones (2008, 2011a). In this respect endophytes of seaweeds are a group worthy of much greater investigation [31][72] [33]. Some preliminary observations on marine-derived fungi from sea grasses [71] and mangrove trees have been reported [62][7]. The fungi reported are primarily asexual morphs, similar to terrestrial counterparts: Aspergillus, Penicillium and Pestalotiopsis spp., and since few of these are fully identified, their marine origin remains to be resolved [33].

Although most natural products studies have focused on antimicrobials, others have looked for antifouling activities and the production of unique enzymes [31] [73].

\section{PRODUCTION OF OMEGA-3-FATTY ACIDS}

The ability of fungus-like organisms, such as thraustochytrids, to produce the polyunsaturated fatty acid docosahexaenoic acid (DHA, c22:6n3) has been known for many years [4][74][60][52]. DHA for commercial use has been extracted from trash fish, but only a few microorganisms can synthesise it as most organisms do not possess the synthetic pathway for its production. Therefore the ability of organisms, such as, Cryptothoconidium cohnii, Thraustochytrium, Schizochytrium and Ulkenia species to produce Poly unsaturated Fatty Acids (PUFA) have attracted considerable interest over the past 20 years. Most research has been undertaken in Hong Kong (Fan et al. 2001), Japan [91][92][53][6].

Studies have focused on strains that produce high yields of PUFA's, especially Schizochytrium spp., and to determine the optimum conditions for DHA production. Surprisingly this is a topic that has not been widely researched in countries bordering the South China Sea. In Hong Kong studies have focused on the physiology of thraustochytrid strains [12][14], and 
their use to enhance the value of waste products such as Okara [11][13]. In Thailand, Unagul et al. (2005) have concentrated on enhancing the growth media for the growth of Schizochytrium mangrovei, especially the effects of glucose, temperature and salinity. The highest yield of DHA reported by Unagul et al. (2005) was 65 $\mathrm{mg} \mathrm{l}^{-1} \mathrm{~h}^{-1}$ (biomass $22.5 \mathrm{gl}^{-1}$ ) and is comparable to those reported by Yokochi et al. (1998) (35 $\left.\mathrm{mg} \mathrm{l}^{-1} \mathrm{~h}^{-1}\right)$ and Fan et al. (2001) (52 $\left.\mathrm{mg} \mathrm{l}^{-1} \mathrm{~h}^{-1}\right)$. Other studies in Thailand examined the enhanced growth of Artemia larvae when fed on different concentrations of thraustochytrid biomass [29], and in particular their potential use in aquaculture [28]. Preliminary studies by Leano et al. (2003) explored the growth and fatty acid production of thraustochytrids isolated in Philippine mangroves.

\section{CONCLUSIONS}

Jones and Vrijmoed in 1993 gave a presentation on the biodiversity marine fungi in South China Sea at a conference on "Perspective on marine environment change in Hong Kong and Southern China 1977-2001". Since then considerable progress has been made to document the fungal biodiversity of this region, as documented above. Marine fungi can be grouped according to their geographical distribution temperate, tropical/subtropical and Arctic/Antarctic, while some are cosmopolitan. Some $50 \%$ of the described marine fungi are tropical and most of these have been recorded from the South China Sea, with 69 new fungi described from this region. New fungi continue to be described from the South China Sea, such as Kitesporella keelungensis and Pileomyces formosanus (64) (63).

Over the past 20 years marine fungi have been screened for a variety of products, in particular compounds with antimicrobial activity from filamentous species, PUFA production from thraustochytrids, and enzymes. Filamentous marine fungi have been shown to produce a diverse range of enzymes as they grow under extreme conditions: high salt tolerance, deep waters, alkaline $\mathrm{pH}$ and low temperatures. Many industries require enzymes that are alkaline tolerant and with optimal activity at low temperatures. Despite this biochemical and physiological diversity, few have been commercially successful.

Compounds produced by marine fungi which have been commercially developed include: cephalosporin $C$ isolated from seawater near a sewage outlet, off the Sardinian coast, phomactins, initially isolated from a Phoma sp. isolated from crab shell and plinabulin, a diketopiperazine halimide, which is in advanced clinical trials for anticancer therapy. What are the challenges for the future? Many new marine fungi remain to be discovered, especially the marine derived taxa (e.g. Aspergillus, Penicillium spp.), which need to be fully described and confirmed by molecular studies to show how they differ from their terrestrial counterparts. Marine yeasts and chytrids have hardly been looked for in the South China Sea, and many substrata need to be examined for fungi: diseases of mangrove plants, corals, mollusc shells, deep-sea water samples and endophytes of seaweeds. Our knowledge on fungus-like organisms is limited to studies of thraustochytrids, and greater effort is required in their study. Biochemical and physiological studies of fungi from the South China Sea have been few and warrants greater attention.

\section{ACKNOWLEDGEMENTS}

K.L. Pang thanks National Science Council of Taiwan for research grants (NSC101-2621-B-019 -001-MY3).

\section{REFERENCES}

1. Alias, S. A. and Jones, E. B. G. (2000a). Colonization of mangrove wood by marine fungi at Kuala Selangor mangrove stand, Malaysia. In: Aquatic mycology across the millennium (eds. Hyde K.D., Ho W.H. and Pointing S.B.). Fungal Diversity Press, Hong Kong, pp. 9-21.

2. Alias, S. A. and Jones, E. B. G. (2000b). Vertical distribution of marine fungi on Rhizophora apiculata at Morib mangrove, Selangor, Malaysia. Mycoscience 41:431-436.

3. Alias, S. A. and Jones, E. B. G. (2009). Marine fungi from mangroves of Malaysia. Institute of Ocean and Earth Studies, No. 8, Kuala Lumpur, Malaysia.

4. Bajpai, P. K., Bajai, P. and Ward, O. P. (1991). Optimization of production of docosahexaenoic acid (DHA) by Thraustochytrium aureum ATCC 34304. J Am Oil Chem Soc 68:509-514.

5. Besitulo, M., Moslem, M. A. and Hyde, K. D. (2010). Occurrence and distribution of fungi in a mangrove forest on Siagao Island. Philippines. Bot Mar 53:535-543.

6. Bowels, R. D., Hunt, A. E., Bremer, G. B., Duchars, M. G. and Eaton, R. A. (1999). Longchain $n-3$ polyunsaturated fatty acid production by members of the marine protistan groups the thraustochytrids: screening of isolates and 
optimisation of docosahexaenoic acids production. J Biotechnol 70:193- 202.

7. Chaeprasert, S., Piapukiew, J., Whalley, A. J. S. and Sihanonth, P. (2010). Endophytic fungi from mangrove plant species of Thailand: their antimicrobial and anticancer potentials. Bot Mar 53:555-564.

8. Chinworrungsee, M., Kittakoop, P., Isaka, M., Rungrod, A., Tanticharoen, M. and Thebtaranonth, Y. (2001). Antimalarial halorosellinic acid from the marine fungus Haloroselliniao oceanica. Bio Med Chem Lett 22:1965-1969.

9. Debbab, A., Aly, A. J. and Proksch, P. (2012). Endophytes and associated marine derived fungiecological and chemical perspectives. Fungal Divers 57:45-83.

10. Ebel, R. (2012). Natural products from marinederived fungi. In: Marine Fungi and Fungal-like Organisms (eds. Jones E.B.G. and Pang K.L.) De Gruyter, Berlin, pp. 411-440.

11. Fan, K. W., Chen, F., Jones, E. B. G. and Vrijmoed, L. L. P. (2001). Eicosapentaenoic and docosahexaenoic acids production and okarautilizing potential of thraustochytrids. J Indust Microbial Biotechnol 227:199-202.

12. Fan, K. W., Vrijmoed, L. L. P. and Jones, E. B. G. (2002a). Physiological studies of subtropical mangrove thraustochytrids. Bot Mar 45:50-57.

13. Fan, K.W. and Chen, F. (2006). Production of high value products by marine microalgae thraustochytrids. In: Bioprocessing for valueadded products from renewable resources (ed. Yang S.T.) Elsevier Science, New York, pp. 293-323.

14. Fan, K.W., Vrijmoed, L. L. P. and Jones, E. B. G. (2002b). Zoospore chemotaxis of mangrove thraustochytrids from Hong Kong. Mycologia 94:569-578.

15. Fell, J.W. (1976). Yeasts in oceanic regions, In: Recent Advances in Aquatic Mycology (ed. Jones E.B.G.) Elek Science, London, pp. 93-124.

16. Fell, J. W. (2012). Yeasts in marine environments. In: Marine Fungi and Fungal-like Organisms (eds. Jones E.B.G. and Pang K.L.) De Gruyter, Berlin, pp. 91-101.

17. Gacutan, V. C. and Uyenco, F. R. (1983).Marine fungi from Batan, Aklan. Appl Sci Bull 35:1-16.

18. Hatai, K. (2012). Diseases of fish and shellfish caused by marine fungi. In: Biology of Marine Fungi (ed. Raghukumar C.) Springer, Berlin, pp. $15-52$.

19. Hatai, K., Bian, Z. B., Baticados, M. C. L. and Egusa, S. (1980). Studies on fungal diseases in crustaceans: II. Haliphthoros philippinensis sp. nov.isolated from cultivated larvae of the jumbo tiger prawn (Penaeus monodon). Trans Mycol Soc Jpn 21:47-55.

20. Ho, H. H., Chang, H. S. and Hsieh, S. Y. (1991). Halophytophthora kandeliae, a new marine fungus from Taiwan. Mycologia 83:419-424.

21. Ho, H. H., Chang, H. S. and Huang, S. H. (2003). Halophytophthora elongata, a new marine species from Taiwan. Mycotaxon 85:417-422.

22. Hyde, K. D. (1989a). Intertidal mangrove fungi from north Sumatra. Can J Bot 67:3078-3082.

23. Hyde, K. D. (1989b).Caryospora mangrovei sp. nov.and notes on marine fungi from Thailand. Trans Mycol Soc Jpn 30:333-341.

24. Hyde, K. D. (1990). A study of vertical zonation of intertidal fungi on Rhizophora apiculata at Kg. Kapok Mangrove. Brunei. Aquatic Bot 336:255-262.

25. Hyde, K. D., Chalermpongse, A. and Boonthavikoon, T. (1990). The distribution of intertidal fungi on Rhizophora apiculata. In: The Marine Biology of the South China Sea. Proc. (ed. Morton B.) 1St Inter Conf on the Marine Biology of Hong Kong and South China Sea, Hong Kong University Press, Hong Kong, pp. 643-652.

26. Hyde, K. D., Goh, T. K., Lu, B. S. and Alias, S. A. (1999). Eleven new intertidal fungi from Nypa fruticans. Mycol Res 103:1409-1422.

27. Isaka, M.,Suyarnsestakorn, C., Tanticharoen, M., Kongsaeree, P. and Thebtaranonth, Y. (2002). Aigialomycins A-E, new resorcylicmacrolides from the marine mangrove fungus Aigialus parvus. J Org Chem 67: 1561-1567.

28. Jarikhuan, S. (2002).Thraustochytrids: a new alternative source of fatty acids for aquaculture. In: Fungi in Marine Environments (ed. Hyde K.D.) Fungal Diversity Press, Hong Kong, pp. 345-357.

29. Jarikhuan, S. and Jones, E. B. G. (2007). Marine microbe (Schizochytrium sp.) from mangrove forest: fatty acid source to Artemia enrichment. Proceedings of the Mangrove Forest Conference on Sufficiency Economy based for Coastal Aquaculture, Thailand, pp. 534-545.

30. Johnson, T. W. and Sparrow, F. K. (1961). Fungi in Oceans and Estuaries. J.Cramer, Germany.

31. Jones, E. B. G. (2008). Bioactive compounds in marine organisms. Bot Mar 51:161-162.

32. Jones, E. B. G. (2011a). Fifty years of marine mycology. Fungal Divers 59: 73-112.

33. Jones, E. B. G. (2011b). Are there more marine fungi to be described? Bot Mar 54:343-354. 
34. Jones, E. B. G. and Agerer, R. (1992).Calathella mangrovei sp. nov. and observations on the mangrove fungus Halocyphina villosa. Bot Mar 35:259 - 265.

35. Jones, E. B. G. and Pang, K. L. (eds.) (2012). Marine Fungi and Fungal-like Organisms. De Gruyter, Berlin.

36. Jones, E. B. G. and Vrijmoed, L. L. P. (1997). Observation on subtropical fungi on driftwood from mangroves and sandy beaches in the Pearl River Estuary. In: Tropical Mycology (eds. Janandhanan K.K., Rajendran C., Natarajan N. and Hawksworth D.L.) Science Publishers Inc., USA, pp.51-59.

37. Jones, E. B. G. and Vrijmoed, L. L. P. (2003). Biodiversity of marine fungi in Hong Kong coastal waters. In: Perspectives on Marine Environment Change in Hong Kong and Southern China 1977-2001, Proceedings of an International Workshop Reunion Conference (ed. Morton B) Hong Kong University Press, Hong Kong, pp. 75-92.

38. E. B. G., Sakayaroj, J., Suetrong, S., Somrithipol, A. and Pang, K. L. (2009). Classification of marine Ascomycota, anamorphic taxa and Basidiomycota. Fungal Divers 35:1-187.

39. Jones, E. B. G., Stanley, S. J. and Pinruan, U. (2008). Marine endophytes sources of new chemical natural products: a review. Bot Mar 51:163-170.

40. Jones, E. B. G., Uyenco, F. R. and Follosco, M. P. (1988). Fungi on driftwood collected in the intertidal zone from the Philippines. Asian Mar Biol 5:103-106.

41. Kohlmeyer, J. and Kohlmeyer, E. (1979). Marine Mycology - the Higher Fungi. Academic Press, New York.pp 1-690.

42. Kupta, J., Anke, T., Steglich, W. and Zechlin, L. (1981). Antibiotics from basidiomycetes. XI. The biological activity of siccayne, isolated from the marine fungus Halocyphina villosa J. \& E. Kohlmeyer. J Antibiot 34:298- 304.

43. Kurtzman, C. P. and Fell, J. W. (2010).The Yeasts: a Taxonomic Study. Elsevier Science Publishers, Amsterdam.

44. Leano, E. M. (2001). Straminipilous organisms from the fallen leaves from Panay Island, Philippines. Fungal Divers 6:75-81.

45. Leano, E. M. (2002). Haliphthoros spp. from spawned eggs of captive mud crab, Scylla serrata, broodstocks. Fungal Divers 9:93-103.

46. Leano, E. M. and Damare, V. (2012). Labyrinthulomycota. In: Marine Fungi and
Fungal-like Organisms (eds. Jones E.B.G. and Pang K.L.) De Gruyter, Berlin, pp. 215-243.

47. Leano, E. M., Gapasin, R. S. J., Polohan, B. and Vrijmoed, L. L. P. (2003).Growth and fatty acid production of thraustochytrids from Panay mangrove, Philippines. Fungal Divers 12:111122.

48. Leano, E. M., Jones, E. B. G. andVrijmoed, L. L. P. (2000). Why are Halophytophthora species so well adapted to mangrove habitats? Fungal Divers 5:131-151.

49. Leano, E. M., Vrijmoed, L. L. P. and Jones, E. B. G. (1998a). Zoospore chemotaxis of two mangrove strains of Halophytophthora vesicula from Mai Po, Hong Kong. Mycologia 90:1001-1008.

50. Leano, E. M., Vrijmoed, L. L. P. and Jones, E. B. G. (1998b). Physiological studies on Halophytophthora vesicula (straminipilous fungi) isolated from fallen mangrove leaves from Mai Po, Hong Kong. Bot Mar 41:411-419.

51. W. F., Tan, T. K. and Jones, E. B. G. (1991). Fungal colonization of submerged Bruguiera cylindrica and Rhizophora apiculata wood. Bot Mar 34:69-76.

52. Lewis, T. E., Nichols, P. D. and McMeekin, T. A. (1999). The biotechnological potential of thraustochytrids. Mar Biotechnol 1:580-587.

53. Li, Z. Y. and Ward, O. P. (1994). Production of docosahexaenoic acid by Thraustochytrium roseum. J Indust Microbiol 13:238-241.

54. Lin, Y. C., Leano, E. M. and Pang, K. L. (2010). Effects of Cu (II) and ZN (II) on growth and cell morphology of thraustochytrids isolated from fallen leaves in Taiwan. Bot Mar 53:581-586.

55. Lin, Y., Wu, X. Y., Feng, S. A., Jiang, G. C., Luo, J. H., Zhou, S. N., Vrijmoed, L. L. P., Jones, E. B. G., Krohn, K., Steingfrover, K. andZsila, F. (2001). Five unique compounds: Xyloketals from mangrove fungus Xylaria sp. from the South China Sea. J Org Chem 66:6252-6256.

56. Luo, W., Vrijmoed, L. L. P. and Jones, E. B. G. (2005). Screening of marine fungi for lignocellulose-degrading enzymes. Bot Mar 48:379-386.

57. Marano, A. V., Pires-Zottarelli, C. L. A., de Souza, J. I., Glocking, S. L., Leano, E., Gachon, C. M. M., Strittmatter, M. and Gleason, F. H. (2012). Hyphochytriomycota, Oomycota and Perkinsozoa (Sub-group Chromalveolata). In: Marine Fungi and Fungal-like Organisms (eds. Jones E.B.G. and Pang K.L.) De Gruyter, Berlin, pp. 167-213.

58. Mei, W. L., Zheng, B., Zhao, Y. X., Zhong, H. M., Chen, X. L. W., Zeng, Y. B., Dong, W. H., 
Huan, J. L., Proksch, P. and Dai, H. F. (2012). Meroterpenes from endophytic fungus A1 of mangrove plant Scyphiphora hydrophyllacea. Mar Drugs 10:1993-2001.

59. Nakagiri, A., Ito, T., Manoch, L. andTanticharoen, M. (2001). A new Halophytophthora species, $H$. porrigovesica, from subtropical mangroves. Mycoscience 42:33-41.

60. Nakahara, T., Yokochi, T., Higashihara, T., Tanaka, S., Yahuchi, T. and Honda, D. (1996). Production of docosahexaenoic acids by Schizochytrium sp. isolated from Yap islands. $J$ Am Oil ChemSoc 73:1421-1426.

61. Neuhauser, S., Glocking, S. L., Leano, E. M., Lilje, O., Marano, A. V. and Gleason, F. H. (2012). An introduction to fungus-like microorganisms. In: Marine Fungi and Fungal-like Organisms (eds. Jones E.B.G. and Pang K.L.) De Gruyter, Berlin, pp. 137-151.

62. Pan, J. Y., Jones, E. B. G., She, Z. Y. and Ling, Y. C. (2008). Review of bioactive compounds from fungi in the South China Sea. Bot Mar 51:179190.

63. Pang, K. L. and Jheng, J. S. (2012a). Pileomyces formosanus gen. et sp. nov. (Halosphaeriaceae, Ascomycota) from a rocky shore of Taiwan. Bot Stud 53:535-539.

64. Pang, K. L. and Jheng, J. S. (2012b). A checklist of marine fungi of Taiwan with a description of Kitesporella keelungensis gen. et sp. nov. Bot Mar 55: 459 - 466.

65. Pang, K. L., Alias, S. A., Chiang, M. W. L., Vrijmoed, L. L. P. and Jones, E. B. G. (2010). Sedeciniella taiwanensis gen. et sp. nov., a marine mangrove fungus in the Hypocreales (Hypocreomycetidae, Ascomycota). Bot Mar 53:493-498.

66. Pang, K. L., Jheng, J. S. and Jones, E. B. G. (2011). Marine Mangrove Fungi of Taiwan. National Taiwan Ocean University Press, Chilung, Taiwan (ROC).

67. Pang, K. L., Vrijmoed, L. L. P., Goh, T. K., Plaingam, N. and Jones, E. B. G. (2008). Fungal endophytes associated with Kandelia candel (Rhizophoraceae) in Mai Po Nature Reserve, Hong Kong. Bot Mar 51:171-178.

68. Pointing, S. B., Vrijmoed, L. L. P. and Jones, E. B. G. (1998). A qualitative assessment of lignocellulose degrading enzyme activity in marine fungi. Bot Mar 41:293-298.

69. Rateb, M. E. and Ebel, R. (2011). Secondary metabolites of fungi from marine habitats. Nat Prod Rep 28:390-344.
70. Sakayaroj, J., Jones, E. B. G., Chatmala, I. and Phongpaichit, S. (2004). Marine fungi. In: Thai Fungal Diversity (eds. Jones E.B.G., Tanticharoen M. and Hyde K.D.) BIOTEC, Thailand, pp. 107-117.

71. Sakayaroj, J., Preedanon, S., Supaphon, O., Jones, E. B. G. and Phongpaichit, S. (2010). Phylogenetic diversity of endophyte assemblages associated with tropical seagrass Enhalus acotoides from Thailand. Fungal Divers 41:27-45.

72. Schulz, B., Draeger, S., dela Cruz, T. E., Rheinheimer, J., Siems, K., Loesgen, S., Bitzer, J., Schloerke, O., Zeeck, A., Kock, I., Hussain, H., Dai, J. and Krohn, K. (2008). Screening strategies for obtaining novel, biologically active fungal secondary metabolites from marine habitats. Bot Mar 51:219-234.

73. Shi, H., Yu, S., Liu, D., van Ofwegen, L.,Porksch, P. and Lin, W. (2012).Sinularones A-I, new cyclopentenone and butenolide derivatives from a marine soft coral Sinularia sp. and their antifouling activity. Mar Drugs 10:1331-1344.

74. Singh, A. and Ward, O. P. (1996). Production of high yields of docosahexaenoic acid by Thraustochytrium aureum ATCC 28210. J Indust Microbiol 16:370-373.

75. Sridhar, K. R. (2012). Decomposition of materials in the sea. In: Marine Fungi and Fungal-like Organisms (eds. Jones E.B.G. and Pang K.L.) De Gruyter, Berlin, pp. 475-500.

76. Sridhar, K. R., Alias, S. A. and Pang, K. L. (2012). Mangrove fungi. In: Marine Fungi and Fungallike Organisms (eds. Jones E.B.G. and Pang K.L.) De Gruyter, Berlin, pp. 253-271.

77. S., Sakayaroj, J., Phongpaichit, S. and Jones, E. B. G. (2009a). Morphological and molecular characteristics of a poorly known marine ascomycete, Manglicola guatemalensis. Mycologia 102:83-92.

78. Suetrong, S., Schoch, C. L., Spatafora, J. W., Kohlmeyer, J., Volkmann-Kohlmeyer, B., Sakayaroj, J., Phongpaichit, S., Tanaka, K., Hairayama, K. and Jones, E. B. G. (2009b). Molecular systematics of the marine Dothideomycetes. Stud Mycol 64:155-173.

79. Tan, T. K., Leong, W. F. and Jones, E. B. G. (1989). Succession of fungi on wood of Avicennia alba and A. lanata in Singapore. Can J Bot 67:2686-2691.

80. Trisuwan, K., Rukachaisirikul, V., Sukpondma, Y., Preedanon, S., Phongpaichit, S., Rungjindamai, N. and Sakayaroj, J. (2008). Epoxydons and a pyrone from the marine-derived fungus Nigrospora sp. PSU-F5. J Nat Prod 71:1323 1326. 
81. Trisuwan, R., Khamthong, N., Rukachaisirikul, V., Phongpaichit, S. and Sakayaroj, J. (2010). Anthraquinone, Cyclopentanone, and Naphthoquinone derivatives from sea fan derivedfungi Fusarium spp., PSU-F14 and PSU-F135. J Nat Prod 73:1507-1511.

82. Unagul, P., Assantachai, C., Phadungruengluij, S., Suphantharika, M., Verduyn, C. (2005). Properties of the docosahexaenoic acid-producer Schizochytrium mangrovei Sk-02: effects of glucose, temperature andsalinity and their interaction. Bot Mar 48: 387-394.

83. Velmurugan, N. and Lee, Y. S. (2012). Enzymes from marine fungi: current research and future prospects. In: Marine Fungi and Fungal-like Organisms (eds. Jones E.B.G. and Pang K.L.) De Gruyter, Berlin, pp.441-475.

84. Vongvilai, P., Isaka, M., Kittakoop, P., Srikitkulchai, P., Kongsaeree, P. and Thebtananonth, Y. (2004). Ketene acetal and spiroacetal constituents of the marine fungus Aigialus parvus BCC 5311. J Nat Prod 67:457-460.

85. Vrijmoed, L. L. P. (2000). Isolation and culture of higher filamentous fungi. In: Marine Mycology-a Practical Approach (eds.Hyde K.D. and Pointing S.B.) Fungal Diversity Press, Hong Kong, pp. 1-20.

86. Vrijmoed, L. L. P., Hodgkiss, I. J. and Thrower, L. B. (1986). Occurrence of fungi on submerged pine and teak blocks in Hong Kong coastal waters. Hydrobiologia 135:109-122.

87. Vrijmoed, L. L. P., Hyde, K. D. and Jones, E. B. G. (1994). Observations on mangrove fungi from Macau and Hong Kong, with the description of two new ascomycetes: Diaporthe salsuginosa and Aniptodera haispora. Mycol Res 98:699-704.

88. Vrijmoed, L. L. P., Jones, E. B. G. and Alias, S. A. (1996). Preliminary observations on marine and mangrove fungi from Hainan island in Southern China. Asian J Tropical Biol 2: 31-38.

89. Wong, M. K. M., Poon, M. O. K. and Hyde, K. D. (1998). Phragmitensis marina gen. et sp. nov., an intertidal saprotroph from Phragmites australis in Hong Kong. Bot Mar 41:379-382.

90. Xia, X. K., Huang, H. R., She, Z. G., Shao, C. L., Liu, F., Cai, X. L., Vrijmoed, L. L. P. and Lin, Y. C. (2007). H and 13C NMR assignment for five anthroquinones from the mangrove endophytic fungus Halorosellinia sp. (No 1403). Magn Reson Chem 45:1006-1009.

91. Yaguchi, T., Tanaka, S., Yokochi, T., Nakahara, T. and Higashihara, T. (1997). Production of high yields of docosahexaenoic acid by Schizochytrium sp. J Am Oil ChemSoc 74:1431-1434.

92. Yolochi,T., Honda, D., Higashihara, T. andNakahara, T. (1998). Optimization of docosahexaenoic acid production by Schizochytrium limacinum SR21. Appl Microbiol Biotechnol49:72-76.

Table 1. Estimated number of marine fungi (Jones 2011b).

\begin{tabular}{lr}
\hline \hline Group & Number \\
\hline Marine fungi & 560 \\
Facultative marine fungi & 100 \\
Marine yeasts & 1500 \\
Misidentified fungi & 100 \\
Marine-derived & 1500 \\
Deep-sea fungi & 300 \\
Planktonic fungi & 500 \\
Endophytes, algicolous and cryptic species & 7500 \\
Total & 12060 \\
\hline
\end{tabular}


Table 2. Estimates of marine fungal-like organisms (Jones and Pang 2012).

\begin{tabular}{lc}
\hline Group & Number \\
\hline Cryptomycota & $5 ?$ \\
Mesomycetozoea & $5 ?$ \\
Oomycota & 74 \\
Hyphochytriomycota & 7 \\
Labyrinthulomycota & 66 \\
Phytomyxea & 9 \\
Total & 966 \\
\hline
\end{tabular}

Table 3. New marine fungi described from countries boarding the South China Sea.

\begin{tabular}{|c|c|c|}
\hline \multicolumn{3}{|l|}{ Ascomycota } \\
\hline Acrocordiopsis sphaerica & Mangrove wood & Philippines \\
\hline Aniptodera haispora & Mangrove wood & Macau \\
\hline Aniptodera intermedia & Nypa fruticans & Malaysia \\
\hline Aniptodera longispora & Mangrove wood & Brunei \\
\hline Aniptodera nypae & Nypa fruticans & Malaysia \\
\hline Anthostomella nypae & Nypa fruticans & Malaysia \\
\hline Anthostomella nypensis & Nypa fruticans & Malaysia \\
\hline Anthostomella nypicola & Nypa fruticans & Malaysia \\
\hline Apioclypea nypicola & Nypa fruticans & Malaysia \\
\hline Arecophila nypae & Nypa fruticans & Malaysia \\
\hline Astrocystis nypae & Nypa fruticans & Malaysia \\
\hline Astrocystis selangorensis & Nypa fruticans & Malaysia \\
\hline Crinispora nypae & Nypa fruticans & Brunei \\
\hline Capillataspora corticola & Rhizophora prop roots & Brunei \\
\hline Caryospora mangrovei & Mangrove wood & Thailand \\
\hline Corollospora besarispora & Mangrove wood & Malaysia \\
\hline Cryptovalsa mangrovei & Kandelia obovata & Hong Kong \\
\hline Dactylospora mangrovei & Mangrove wood & Hong Kong, Malaysia, Taiwan, Thailand \\
\hline Fasciatispora lignicola & Mangrove wood & Malaysia \\
\hline Fasciatispora nypae & Nypa fruticans & Brunei \\
\hline Halosarpheia kandeliae & Kandelia obovata & Hong Kong \\
\hline Halosarpheia minuta & Mangrove wood & Singapore \\
\hline Helicascus nypae & Nypa fruticans & Brunei \\
\hline Herpotrichia nypicola & Nypa fruticans & Malaysia \\
\hline Hypophloeda rhizophora & Nypa fruticans & Brunei \\
\hline Frondicola tunitricuspis & Mangrove wood & Brunei \\
\hline Kitesporella keelungensis & Mangrove wood & Taiwan \\
\hline
\end{tabular}




\begin{tabular}{|c|c|c|}
\hline Lautospora gigantea & Mangrove wood & Brunei \\
\hline Leprosphaerulia mangrovei & Acanthus ilicifolius & Hong Kong \\
\hline Leptosphaeria nypicola & Nypa fruticans & Malaysia \\
\hline Ligninicola nypae & Nypa fruticans & Malaysia \\
\hline Linocarpon nypae & Nypa fruticans & Malaysia \\
\hline Marinosphaera mangrovei & Mangrove wood & Brunei \\
\hline Massarina acrostichi & Fern Acrostichum sp. & Brunei \\
\hline Melaspilea mangrovei & Mangrove wood & Hong Kong \\
\hline Nemania maritimqa & Mangrove wood & Taiwan \\
\hline Neolinocarpon globosicarpum & Nypa fruticans & Brunei \\
\hline Neolinocarpon nypicola & Nypa fruticans & Malaysia \\
\hline Nipicola selangorensis & Nypa fruticans & Malaysia \\
\hline Nypaella frondicola & Nypa fruticans & Brunei \\
\hline Oxydothis nypae & Nypa fruticans & Brunei \\
\hline Payosphaeria minuta & Mangrove wood & Singapore \\
\hline Pedumispora rhizophorae & Mangrove wood & Brunei \\
\hline Phomatospora kandelae & Mangrove wood & Thailand \\
\hline Phomatospora nypae & Nypa fruticans & Malaysia \\
\hline Phomatospora nypicola & Nypa fruticans & Malaysia \\
\hline Phragmitensis marina & Phragmites australis & Hong Kong \\
\hline Pileomyces formosanus & Driftwood & Taiwan \\
\hline Remispora minuta & Driftwood & Singapore \\
\hline Sablecola chinensis & Driftwood & Singapore \\
\hline Salsuginea ramicola & Mangrove wood & Brunei \\
\hline Saccardoella mangrovei & Mangrove wood & Malaysia \\
\hline Saccardoella marinospora & Mangrove wood & Brunei \\
\hline Saccardoella rhizophorae & Mangrove wood & Thailand \\
\hline Savoryella longispora & Mangrove wood & Thailand \\
\hline Sedecimiella taiwanensis & Mangrove wood & Taiwan \\
\hline Thalespora appendiculata & Mangrove wood & Thailand \\
\hline Tirispora unicaudata & Mangrove wood & Hong Kong \\
\hline Tirisporella beccariana & Nypa fruticans & Malaysia \\
\hline Trematosphaeria malaysiana & Mangrove driftwood & Malaysia \\
\hline Vibrissea nypicola & Nypa fruticans & Malaysia \\
\hline \multicolumn{3}{|l|}{ Asexual morphs } \\
\hline Arthrobotrys mangrovispora & Mangrove wood & Hong Kong \\
\hline Phomopsis mangrovei & Rhizophora prop roots & Thailand \\
\hline Plectophomella nypae & Nypa fruticans & Brunei \\
\hline Pleurophomopsis nypae & Nypa fruticans & Brunei \\
\hline Trichocladium nypae & Nypa fruticans & Malaysia \\
\hline
\end{tabular}




\begin{tabular}{lll}
\hline Basidiomycota & \\
Calathella mangrovei & Bruguiera sp. & Malaysia \\
Physalacria maipoensis & Mangrove wood & Hong Kong \\
\hline \hline
\end{tabular}

Table 4. Number of marine fungi recorded for the South China Sea.

\begin{tabular}{lc}
\hline \hline Country & Number \\
\hline Thailand & 154 \\
Malaysia & 139 \\
Hong Kong & 117 \\
Taiwan & 107 \\
Philippines & 80 \\
Brunei & 68 \\
Indonesia & 48 \\
Singapore & 41 \\
Vietnam & 5 \\
\hline \hline
\end{tabular}

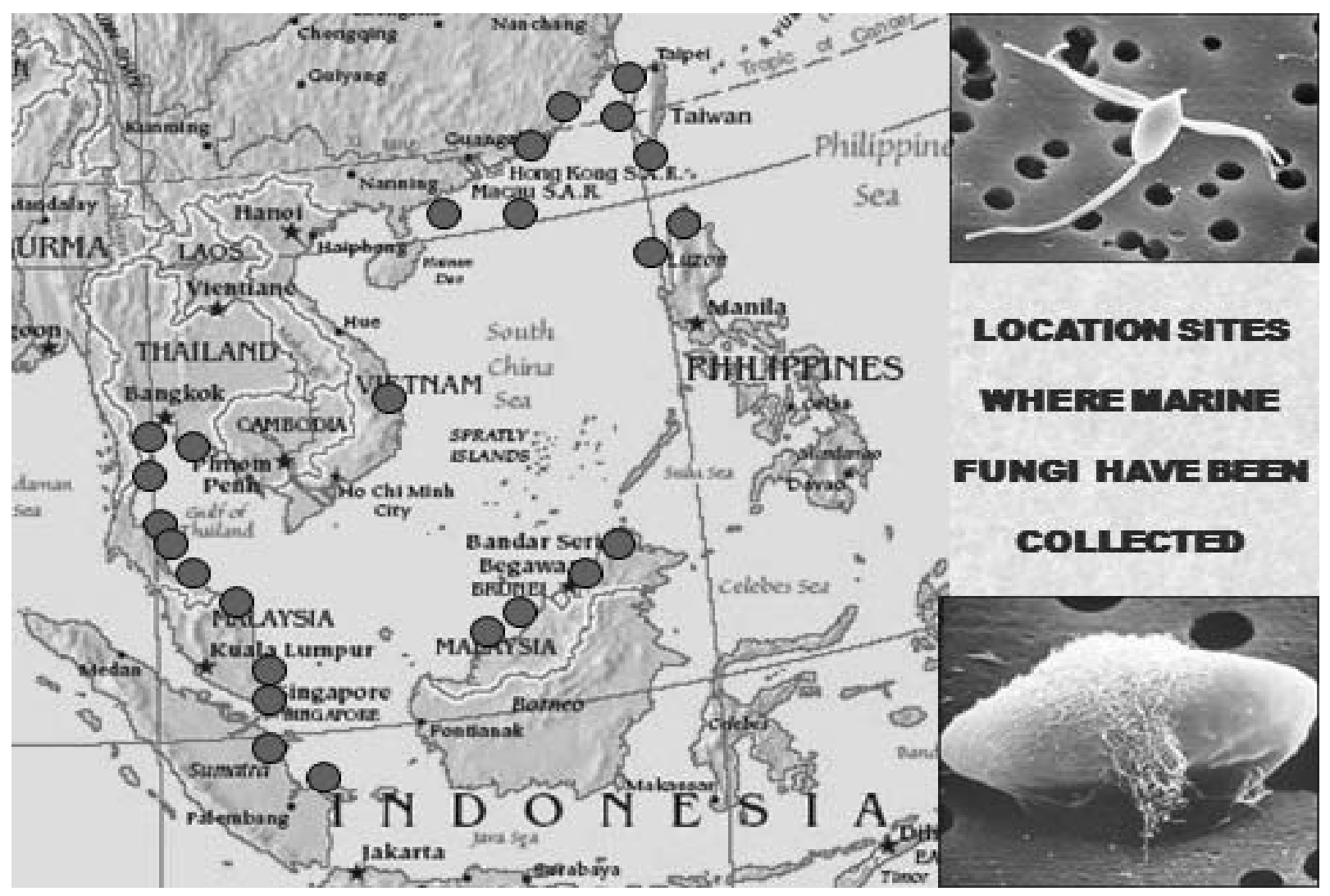

Figure 1. Distribution of sites surveyed for marine fungi (Jones, unpublished data) 
Malaysian Journal of Science 32 (SCS Sp Issue) : 95-106 (2013) 